\title{
Chapter 11 \\ On the Tracks of Neandertals: The \\ Ichnological Assemblage from Le Rozel (Normandy, France)
}

\author{
Jérémy Duveau, Gilles Berillon, and Christine Verna
}

\begin{abstract}
Hominin tracks represent a unique window into moments in the life of extinct individuals. They can provide biological and locomotor data that are not accessible from skeletal remains. However, these tracks are relatively scarce in the fossil record, particularly those attributed to Neandertals. They are also most often devoid of associated archaeological material, which limits their interpretation. The Palaeolithic site of Le Rozel (Normandy, France) located in a dune complex formed during the Upper Pleistocene has yielded between 2012 and 2017 several hundred tracks (257 hominin footprints, 8 handprints as well as 6 animal tracks). This ichnological assemblage is distributed within five stratigraphic subunits dated to 80,000 years. These subunits are rich in archaeological material that attests to brief occupations by Neandertal groups and provides information about the activities that they carried out. The ichnological assemblage discovered at Le Rozel is the largest attributed to Neandertals to date and more generally the most important for hominin taxa other than Homo sapiens. The particularly large number of footprints can provide major information for our understanding of the Palaeolithic occupations at Le Rozel and for our knowledge of the composition of Neandertal groups.
\end{abstract}

Keywords Group composition · Morphometry $\cdot$ Footprint $\cdot$ Neandertals $\cdot$ Le Rozel

\section{Introduction}

Tracks, and especially footprints, are unique vestiges that provide direct information on the locomotor and biological characteristics (e.g. stature, body mass, age) of hominin groups (e.g. Bennett et al. 2009; Crompton et al. 2011; Bennett and Morse 2014). Such information can be obtained from trackways (e.g. Leakey and Hay 1979; Masao et al. 2016; Roach et al. 2016) or from isolated footprints by using

\footnotetext{
J. Duveau $(\bowtie) \cdot$ G. Berillon · C. Verna

UMR 7194 HNHP, Centre National de la Recherche Scientifique, MusÕum national d'Histoire naturelle, Université Perpignan Via Domitia, Paris, France

e-mail: jeremy.duveau@edu.mnhn.fr
} 
morphometric methods (Dingwall et al. 2013; Ashton et al. 2014; Citton et al. 2017) or expert tracker readings (Pastoors et al. 2015, 2017). Ichnological assemblages require a quick sedimentary burial to be preserved in an open-air context; this differs from the cave context, where they are usually found at the surface of the soil (see Chap. 4). As it, they represent an original snapshot on the composition of groups and their behaviours during their lives (e.g. Mastrolorenzo et al. 2006; Hasiotis et al. 2007; Schmincke et al. 2010; Falkingham 2014). They differ in this respect from skeletal or lithic material whose accumulations may have occurred during various and repeated occupations over long periods (Farizy 1994; Pettitt 1997). However, the study of tracks is usually a challenging task. Indeed, if their morphology reflects the biological and locomotor characteristics of trackmakers, they are also affected by the nature of substrate and by taphonomic modifications (e.g. Allen 1997; Bennett and Morse 2014; see Chap. 2). In addition, despite several significant discoveries in recent years (e.g. Altamura et al. 2018; Bustos et al. 2018; McLaren et al. 2018; see Chap. 5), the number of sites that yielded hominin tracks is relatively low compared to sites with archaeological and palaeoanthropological material (e.g. Kim et al. 2008; Lockley et al. 2008, 2016; Bennett and Morse 2014). This rarity is even more important for the footprints attributed to Neandertals since only nine footprints found at four sites attributed to this taxon were reported to date (Fig. 11.1).

In this context, here we present the largest ichnological assemblage attributed to Neandertal discovered at the archaeological site from Le Rozel (Manche, France). We present first a synthesis of the previously known footprints attributed to Neandertals. Then the archaeological site of Le Rozel will be presented before describing

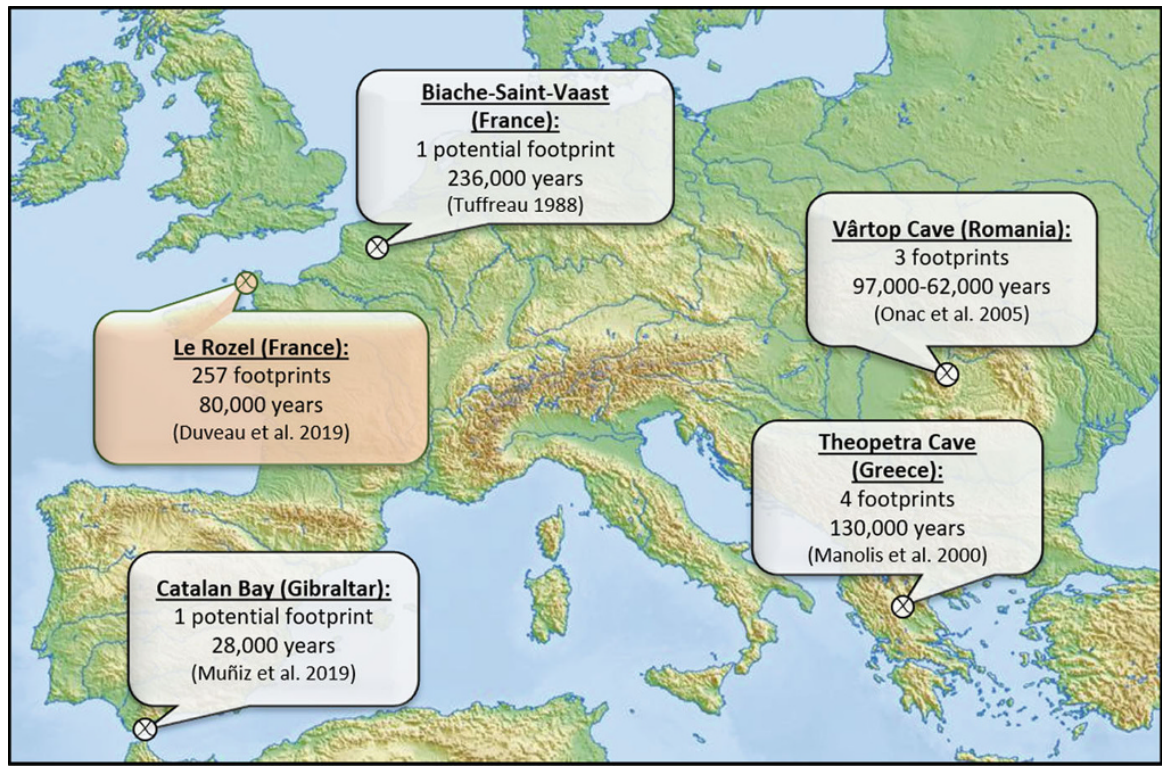

Fig. 11.1 Geographical distribution of the footprints attributed to Neandertals 
the ichnological sample discovered there between 2012 and 2017. Finally, the importance of this assemblage in relation to other sites that yielded hominin footprints, and in particular those attributed to Neandertals, will be discussed before concluding on the potential of these footprints to yield direct information on the trackmaker groups that lived at Le Rozel 80,000 years ago.

\section{The Neandertal Footprint Record}

The oldest track attributed to Neandertals is also the first that has been described: it is a single footprint discovered in 1976 in a silty ground at the Middle Pleistocene site of Biache-Saint-Vaast (France) (Tuffreau 1978, 1988). It is associated with two fragmentary human skulls that bear Neandertal features as well as with archaeological material including lithic industry and 236,000-year-old faunal remains (Tuffreau 1988; Rougier 2003; Guipert et al. 2011; Bahain et al. 2015). The attribution of the track to a Neandertal individual is based on the cranial remains and on the associated archaeological material. This footprint is poorly preserved and was probably damaged by bovid trampling making its identification as a hominin footprint and its analysis difficult (Tuffreau 1988).

Four footprints were discovered in 1996 in the Greek cave of Theopetra. They were made in a clay substrate dated by thermoluminescence to 130,000 years (Manolis et al. 2000; Valladas et al. 2007; see Chap. 10). They are associated with a Mousterian industry that allows to attribute them to Neandertals (Manolis et al. 2000; Valladas et al. 2007). The four footprints were probably made by different individuals with their left feet. The second and the third footprints are relatively complete. They are 14 and $15 \mathrm{~cm}$ long and were made by young children whose ages and statures are estimated to 2 and 4 years and to 86 and $100 \mathrm{~cm}$ (Manolis et al. 2000). Furthermore, Manolis et al. (2000) suggest that the third footprint was made by a shod individual, which would represent the oldest occurrence of a shoe among hominins. Casts of the footprints were realized, and the two most complete were 3D digitized (Manolis et al. 2000).

Three footprints made in calcareous mud dated by U-Th between 97,000 and 62,000 years were discovered in the Romanian Vârtop Cave (Onac et al. 2005; see Chap. 12). No archaeological or palaeoanthropological material was associated with these tracks. The taxonomic attribution to Neandertals is based only on the chronological age, Neandertals being the only taxon known in Europe for this time period. The three footprints were made by a single individual (Onac et al. 2005; Harvati and Roksandic 2016). Two of them are partial, consisting only of either heel or forefoot impressions. The third footprint is longitudinally complete; it is $22 \mathrm{~cm}$ long and was made by an individual whose height was estimated to $146 \mathrm{~cm}$ (Viehmann 1987). It is characterized by a space described as important $(1.6 \mathrm{~cm})$ between the hallux and the second toe impressions (Onac et al. 2005). Its morphology would reflect the robust Neandertal anatomy (Onac et al. 2005). 
More recently, a potential human footprint was discovered in the dune complex of Catalan Bay at Gibraltar. OSL dating of the aeolian unit where the footprint was made provided an age of 28,000 years (Muñiz et al. 2019). This footprint is described as poorly preserved. It is $17 \mathrm{~cm}$ long and was made by an individual whose height is estimated between 106 and $126 \mathrm{~cm}$ and who was descending a slope (Muñiz et al. 2019). No archaeological or palaeoanthropological remains are associated with this footprint. Moreover, its morphology does not allow to discard Homo sapiens as the possible trackmaker (Muñiz et al. 2019). Therefore, the taxonomic attribution to a Neandertal individual is only based on the discovery a few kilometres away of archaeological material that would indicate that Neandertal groups may have lived in the region until 28,000 years BP (Finlayson et al. 2006). However, the dating of this material is questioned not only as regards stratigraphic consistency (Delson and Harvati 2006) but also for methodological aspects (Wood et al. 2013). Therefore, the lack of consensus on these dates combined with the fact that the footprint would correspond to the last Neandertal occurrence raises questions about the validity of the taxonomic attribution to a Neandertal individual.

In this synthesis on footprints attributed to Neandertals, it is necessary to mention those discovered in the Romanian cave of Ciur Izbuc (Webb et al. 2014; see Chap. 12). The research undertaken at this cave yielded 400 human footprints, dated between 36,500 and 29,000 years calBP, before three quarters of them were destroyed (Webb et al. 2014). The absence of archaeological or palaeoanthropological material associated with the footprints makes their taxonomic attribution complex. Indeed, the lowest limit of the chronological interval is close to the last occurrence of Neandertals reported in central and Eastern Europe (Pinhasi et al. 2011; Devièse et al. 2017). However, skeletal remains provided evidence of the occurrence of Homo sapiens in Romania around the period when the footprints were made (Trinkaus et al. 2003; Soficaru et al. 2007; Higham et al. 2011). It is thus more likely that these footprints were made by Homo sapiens (Webb et al. 2014).

Lastly, the footprints discovered in the Italian site of Bàsura Cave were for a long time attributed to Neandertals (Pales 1954, 1960). For this attribution, L. Pales used the presence of a Mousterian industry in a nearby cave and remains of cave bears that he considered as contemporary to Neandertals. However, subsequent radiocarbon dating on charcoals discovered in the same layer as the footprints invalidated their taxonomic attribution to Neandertals, showing instead that they were made by Homo sapiens (Molleson et al. 1972; De Lumley and Vicino 1984).

\section{The Archaeological Site from Le Rozel}

Located on the western coast of the Cotentin (Manche, Normandy) (Fig. 11.1), Le Rozel $\left(49^{\circ} 28^{\prime} 20.92^{\prime \prime} \mathrm{N}, 1^{\circ} 50^{\prime} 25.58^{\prime \prime} \mathrm{W}\right)$ is part of a dune formation in a creek opened in a schist cliff. This dune complex is composed of soft aeolian sand and was formed during the end of the Eemian and the beginning of the Last Glacial Period, between 115,000 and 70,000 years ago (Van Vliet-Lanoë et al. 2006). The 
site was discovered in the 1960s by Yves Roupin following coastal erosion that uncovered several faunal bones at the base of the dune. These initial discoveries led to a survey in 1967 and to the first excavations in 1969 directed by Frédéric Scuvée (Scuvée and Verague 1984). The monitoring of the site since the 1980s has revealed significant damages caused by erosion and led to annual excavations under the direction of D. Cliquet since 2012.

Le Rozel shows a long stratigraphic sequence (Fig. 11.2) dominated by detrital elements brought by wind dynamics (Van Vliet-Lanoë et al. 2006). This sequence is delimited at its summit by a 6- to 8-m-thick head above a palaeodune massif. The archaeological layers discovered since 2012 are located within five stratigraphic subunits of this palaeodune (D3b-1 to D3b-5) composed of fine to medium sand (Cliquet et al. 2018a, b). The OSL dating carried out within the stratigraphic sequence places these subunits around 80,000 years (Mercier et al. 2019). Furthermore, geochronological and sedimentary analyses have shown that the stratigraphic subunits were formed and covered quickly (Mercier et al. 2019) which means that each subunit represents a relatively short and likely single occupation phase. The first three subunits (D3b-1 to D3b-3) are composed of subhorizontal organic soils, brown to black in colour, and consist of degraded dune sand where lithic industries, charcoals, faunal remains and tracks were discovered (Fig. 11.3). The Palaeolithic

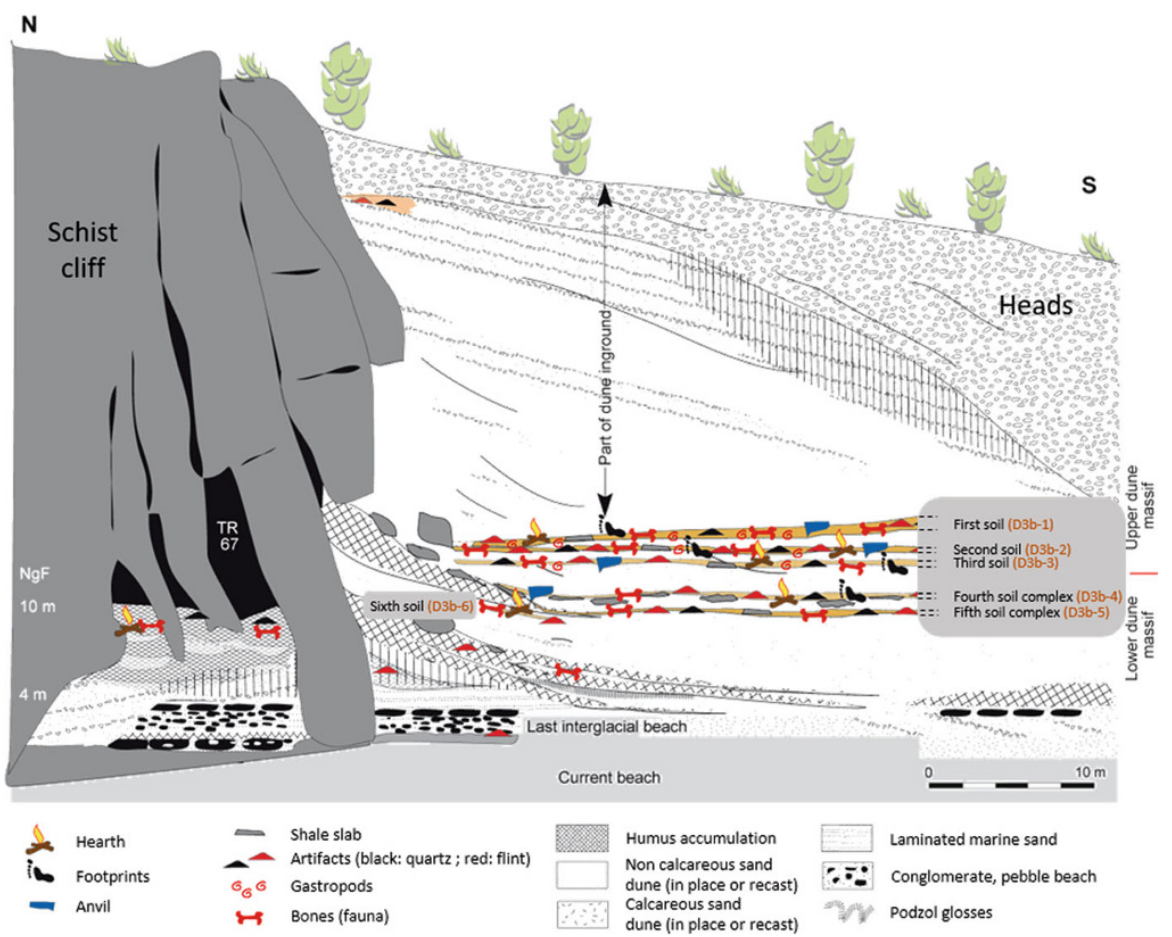

Fig. 11.2 Cross section of the dune complex from Le Rozel and locations of the Palaeolithic occupations. (Modified from Cliquet et al. 2018b) 

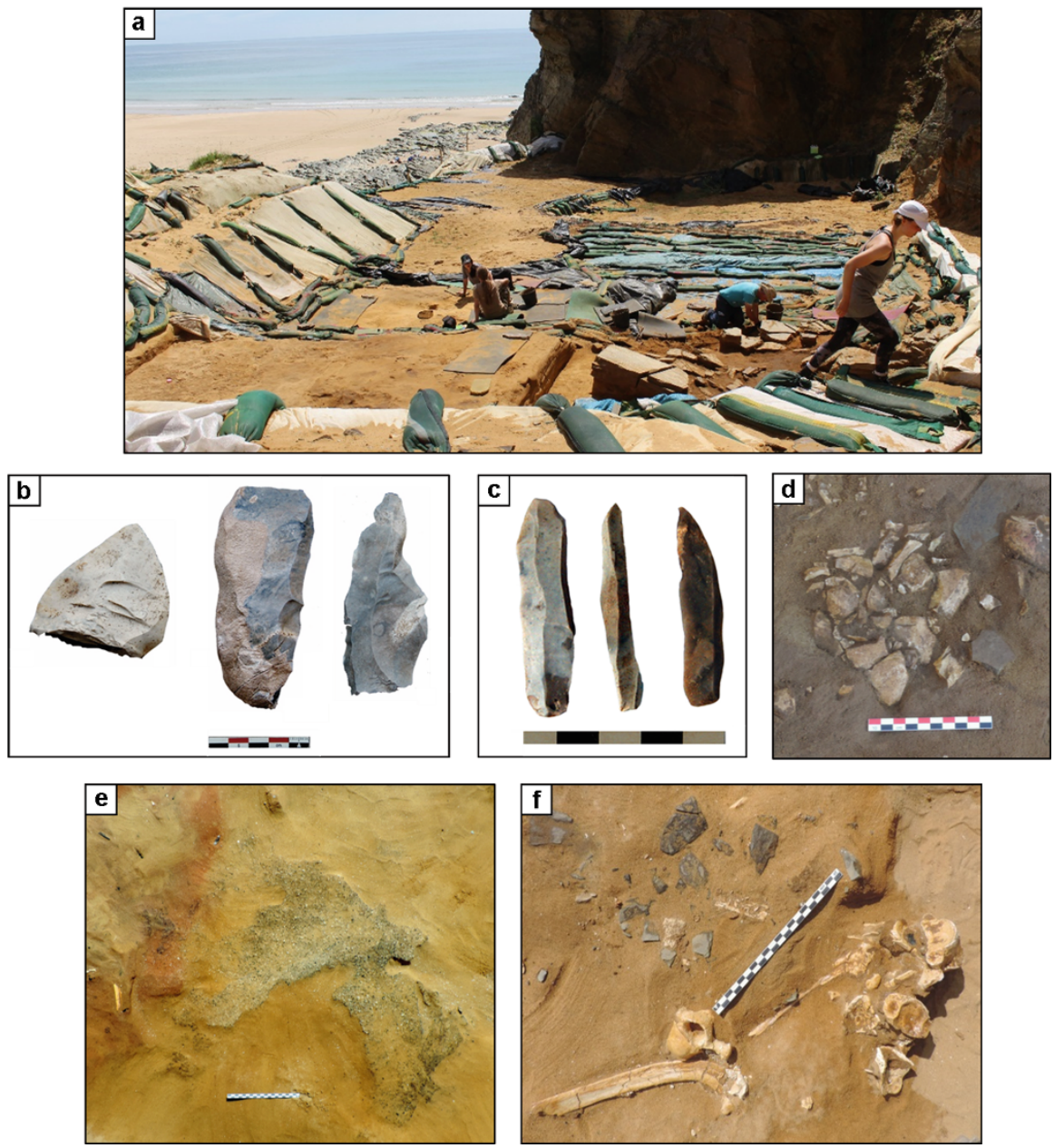

Fig. 11.3 The archaeological site from Le Rozel; (a) view of the site; (b) Levallois flakes; (c) blades; (d) knapping spot; (e) hearth; (f) butchery area. (Photos D. Cliquet)

activities in these soils seem to be structured around hearths and, for the D3b-2 and D3b-3 subunits, knapping spots (Cliquet et al. 2018a, b). The D3b-4 and D3b-5 subunits, whose excavations are still in progress, are affected by numerous intertwined mudflows that are intersected by small schist plates. These subunits yielded lithic industries, knapping spots, hearths, faunal remains and most of the tracks (Cliquet et al. 2018a, b). Below these stratigraphic subunits are the occupation layers identified and studied by Scuvée during the 1960s (Scuvée and Verague 1984). Two layers (Scuvée E2 and Scuvée E3) were located at the base of the dune and included faunal remains and lithic industry, while a third layer (Scuvée F2) was located inside a rock shelter (TR 67) where hearths, faunal remains and lithic 
artefacts were discovered (Scuvée and Verague 1984; Van Vliet-Lanoë et al. 2006; Cliquet et al. 2018a, b).

The analyses carried out on the archaeological material discovered at Le Rozel show that two techno-cultural worlds were operated by the human groups 80,000 years ago (Cliquet et al. 2018a, b). This dichotomy observed between the two sets of occupations is particularly visible with the lithic industries. Indeed, although the raw materials and their relative frequency are similar between the upper and lower subunits (a majority of local flint and to a lesser extent quartz; anecdotal use of sandstone and mylonite), the characteristics of the industry differ. The industries discovered in subunits D3b-1 to D3b-3 mainly represent direct debitage flakes and Levallois flakes. The D3b-4 and D3b-5 ones correspond to a higher proportion of lamellar and laminar productions. While some blades come from the production of direct debitage flakes or Levallois flakes, a lot of them have been obtained by semi-rotating or rotating debitages (Cliquet et al. 2018a, b).

The three more recent upper subunits (D3b-1 to D3b-3) provide evidence of butchery activities (Fig. 11.3), whereas site function for the lower subunits (D3b-4, D3b-5, Scuvée E2-E3, Scuvée F2) is not yet established (Cliquet et al. 2018a, b).

Within the D3b-1 to D3b-3 subunits, the fauna consumed is largely dominated by red deer, horse and aurochs, both in terms of number of remains and minimum number of individuals (Sévêque 2017). The bones of these three species bear the characteristic stigmata of skinning, dismantling and the recovery of meat. The study of the slaughter periods of this fauna enabled to estimate that Palaeolithic occupations took place during bad weather seasons, between autumn and spring (Sévêque 2017; Cliquet et al. 2018b). Other bones belong to straight-tusked elephant, grassland rhinoceros, roe deer and rabbit whose nutritional usefulness is not confirmed. Anthracological analyses show that the hearths were mainly composed of Scots pine and yews, which could reflect a vegetal selection. Anthracological and zooarchaeological material provide a representation of the environments during the Palaeolithic occupations of the site (Stoetzel et al. 2016; Sévêque 2017; Cliquet et al. 2018a, b): they are characteristic of a temperate climate and open landscapes, including humid temperate semi-wooded meadows.

The lower subunits (D3b-4 and D3b-5) are less informative than the first three; only the large fauna, which is weakly conserved, provides results. In these layers, red deer is once again the most frequent, with horse and aurochs (Sévêque 2017; Cliquet et al. 2018a, b).

In the absence of human osteological remains, the Palaeolithic occupations at Le Rozel are attributed to Neandertals by considering the chronostratigraphic context and the characteristics of the archaeological material. On the one hand, the D3b-1 to D3b-5 subunits are dated to 80,000 years when Neandertals were the only taxon known in Europe (Benazzi et al. 2011; Nigst et al. 2014; Hublin 2015). On the other hand, the technological features of the archaeological material, especially that of the upper subunits, have already been observed on other Mousterian sites associated with Neandertal remains (Cliquet et al. 2018b). The cultural dichotomy between the upper and the lower subunits suggests the presence of different groups. 


\section{Material and Methods}

The analysis of the ichnological set discovered between 2012 and 2017 at Le Rozel led to the identification of 271 tracks including 257 hominin footprints, 8 hominin handprints (Fig. 11.4) as well as 6 animal tracks (Duveau et al. 2019).

These tracks were identified by morphological criteria; they had to reflect the anatomy and the locomotor behaviour of the trackmakers. More particularly, human footprints reflect a rounded heel, a narrow midfoot, relatively short toes including a robust and adducted hallux (e.g. Aiello and Dean 1990; Klenerman and Wood 2006; Morse et al. 2010; Bennett and Morse 2014). The heel and forefoot impressions are deeper than that of the midfoot (Crompton and Pataky 2009; Morse et al. 2010; Bennett and Morse 2014). Moreover, the identification of the human footprints was reinforced by using the morphometric test developed by Morse et al. in 2010 (Duveau et al. 2019). Human handprints are recognizable by the impressions of a rounded palm, relatively wider than the heel of the foot, and the fingers are relatively long except the thumb which is smaller. This thumb has an abduction capacity unlike the human hallux (e.g. Aiello and Dean 1990; Jones and Lederman 2006). At last, the animal tracks were identified and taxonomically attributed thanks to identification criteria from the literature (e.g. Bang et al. 2001; Murie and Elbroch 2005).

Each track was photographed and described in situ. Casts were made of 64 tracks between 2013 and 2016. Seventy original tracks were directly extracted after a chemical consolidation of the substrate in 2017. The casts and extracted footprints are curated in the premises of the Direction Régionale des Affaires Culturelles (DRAC, Caen, France). 180 tracks including 170 footprints were digitized in 3D.
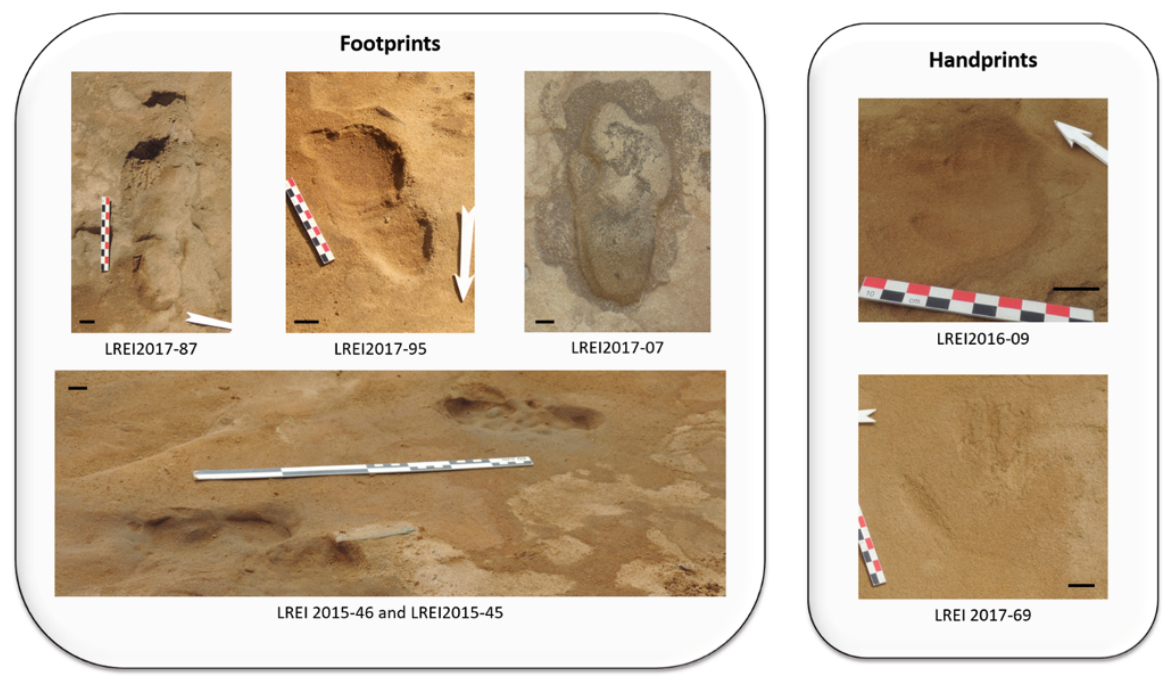

Fig. 11.4 Hominin footprints and handprints discovered at Le Rozel. (Photos D. Cliquet) (scale bar : 10 and $40 \mathrm{~cm}$ ) 
Seventy-seven footprints were digitized by using photogrammetry with the Agisoft Protocan software (v.1.4.0) and a Canon EOS 1300D camera. 137 footprints were 3D modelled by using a Noomeo OptiNum surface scan. The use of these different acquisition techniques required that we run morphometric comparisons between them prior to analysis. These comparisons did not detect any differences between the types of acquisition (Duveau et al. 2019).

Besides, each track was measured in situ. These measurements were controlled and specified on the tracks digitized in 3D by using Geomagic Studio 2013. The length was measured along the longitudinal axis. For footprints, this axis is from the most proximal point of the heel to the distal end of the second toe. Therefore, length measurement requires that the footprint is longitudinally complete and that the toe impressions can be differentiated from the rest of the print. In addition, we measured the maximum width of the forefoot, along a mediolateral axis perpendicular to the longitudinal axis. The lengths and widths of the footprints from Le Rozel were compared to those of the other footprints attributed to Neandertals using published data: two of the four footprints from Theopetra Cave (Manolis et al. 2000), the most complete footprint from Vârtop Cave (Onac et al. 2005) and the potential footprint from Catalan Bay (Muñiz et al. 2019).

\section{Results}

\section{Preservation and Distribution of the Tracks}

The 271 discovered tracks have been preserved thanks to a rapid sedimentary cover by aeolian sand. Indeed, experimental observations carried out in situ have shown that without this protection, the tracks could have been damaged, if not entirely destroyed, in a few tens of minutes. Due to the erosive action of the wind on the tracks, as well as other taphonomic agents, this ichnological assemblage probably represents only a sample of the initial assemblage left by the trackmakers $\sim 80,000$ years ago.

The tracks come from the subunits D3b-1 to D3b-5 and were discovered in the same layers as the archaeological material. Nearly $80 \%$ of the reported tracks come from the D3b-4 stratigraphic subunit, which extends over more than $90 \mathrm{~m}^{2} ; 11 \%$ of the tracks come from the D3b-5 subunit; the rest of the tracks are similarly distributed among the three other subunits. Among the 271 tracks, 198 were made in sandy mud and 73 in dune sand. The tracks made in dune sand, which mainly come from the D3b-1 to D3b-3 subunits, are less well preserved (i.e. they reflect less anatomical details and in particular less clear toe impressions) than those made in sandy mud that come from the D3b-4 and D3b-5 subunits. This differential conservation partly explains the differences in distribution between the subunits. The depth of the tracks is highly variable, from a few millimetres to $5 \mathrm{~cm}$, and may suggest varying moisture conditions when they were made. 


\section{Human Footprints}

Description: Among the 257 footprints, 5 trackways composed of 2 to 3 footprints were reported (Fig. 11.4), the rest of the footprint set consisting of isolated tracks. They include 112 left prints, 115 right prints and 30 impressions of indeterminate laterality. Footprint morphology is variable which is common for footprints made in soft substrate (e.g. Allen 1997; Morse et al. 2013; Bustos et al. 2018), such as dune sand or sandy mud. The quality of the prints is variable, and some are partial. Ten prints correspond only to the heel impressions, and three reflect only the forefoot. Eighty-eight footprints are longitudinally complete since they show proximally the impressions of rounded heels and distally clear impressions of the tip of the toes. Of these longitudinally complete footprints, not all the toes are systematically printed. The hallux impression and to a lesser extent that of the second toe are the most common and the deepest toe impressions. With one exception, the hallux impression is always visible when the impressions of toes can be distinguished from the rest of the footprint. The remaining 156 footprints reflect a relatively complete foot outline but do not provide evidence, such as variation in depth, allowing to distinguish the toe impressions. It is therefore difficult to attest that they are longitudinally complete.

The best-preserved footprints reflect morphological features close to those of humans including a fully adducted hallux and a midfoot mediolaterally narrow. Moreover, the heel and forefoot impressions are the deepest areas of the footprints; the forefoot is on average deeper than the heel. The midfoot impression is shallow and has a slight outline. This depth distribution and the narrowing of the midfoot impression are consistent with an architecture of the foot in vault. These architectural characteristics are less pronounced for the smallest footprints, which suggest a flatter foot for the youngest individuals. They are also less marked compared to footprints made by Homo sapiens (Duveau et al. 2019), which is consistent with our knowledge of the anatomy of the Neandertal foot, which was more robust and had a less pronounced plantar arch than the Homo sapiens foot (Trinkaus et al. 1991; Berillon 2000).

Comparative morphometry: The 3D modelling of 169 footprints allows accurate morphometric comparisons according to the subunits (Fig. 11.5a). These comparisons were carried out on footprints sufficiently complete that were made on horizontal layers and that do not show any evidence of sliding. The footprints from the D3b-4 stratigraphic subunit, the densest in tracks, have lengths ranging from 11.4 to $28.4 \mathrm{~cm}$ (mean, $19.2 \mathrm{~cm}$ ) and widths from 4.5 to $12.8 \mathrm{~cm}$ (mean, $8.4 \mathrm{~cm}$ ). The exploitable footprints from the other stratigraphic subunits fall within these ranges (Fig. 11.5). The footprints from the D3b-1 subunit are shorter $(12.3-18.4 \mathrm{~cm})$ and narrower (mean, 5.1-8.4 cm) than the average of those from the D3b-4. The footprints from the D3b-2 and D3b-3 subunits are on average longer (respectively, $21.4 \mathrm{~cm}$ and $22.0 \mathrm{~cm}$ ) but have close average widths $(8.1 \mathrm{~cm}$ and $8.7 \mathrm{~cm})$. Finally, the footprints from the D3b-5 subunit are biometrically close to those from the D3b-4 for both length (mean, $19.7 \mathrm{~cm}$ ) and width (mean, $7.9 \mathrm{~cm}$ ). The lengths and widths of the other footprints attributed to Neandertals fall within the ranges of those 

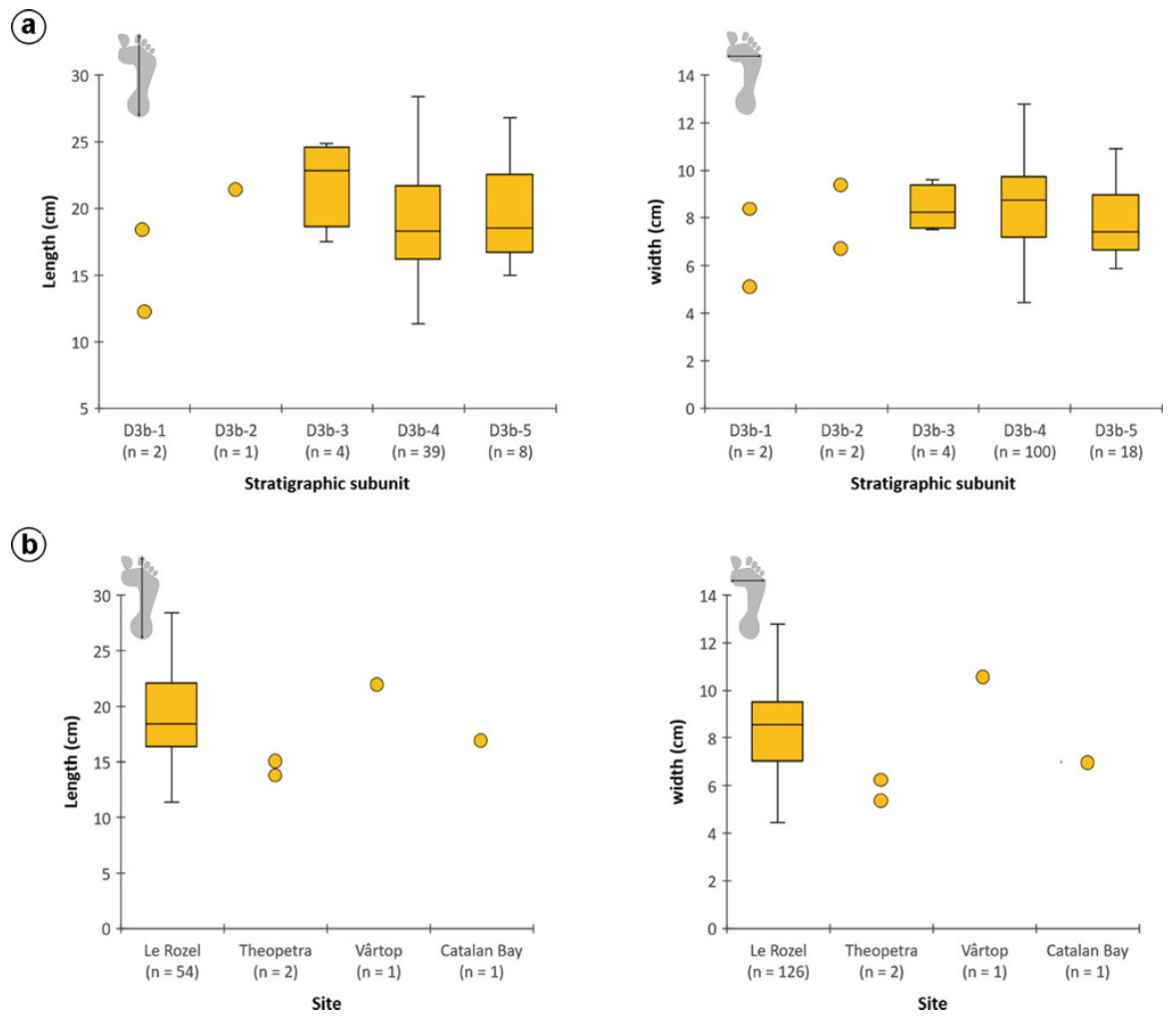

Fig. 11.5 Dimensions of the Le Rozel footprints digitized in 3D; (a) depending on their locations in the stratigraphic subunits; (b) compared to the other footprints attributed to Neandertals

from Le Rozel (Fig. 11.5b). The two footprints from Theopetra Cave (14 and $15 \mathrm{~cm}$ long, 5 and $6 \mathrm{~cm}$ wide) and the footprint from Catalan Bay $(17 \mathrm{~cm}$ long and $7 \mathrm{~cm}$ wide) are relatively smaller than the averages of the Le Rozel footprints $(19,2 \mathrm{~cm}$ long and 8,4 $\mathrm{cm}$ wide). On the other hand, the footprint from Vârtop Cave is relatively longer $(22 \mathrm{~cm})$ and wider $(11 \mathrm{~cm})$.

\section{Human Handprints}

The eight handprints all reflect a right laterality. As with footprints, their morphology is variable. Six handprints are longitudinally complete with lengths ranging from 11.4 to $16.1 \mathrm{~cm}$. The two other handprints show fingerprints but not clearly the base of the palm. The handprints are characterized by a broad palm, deep and long fingerprints (relatively longer than toe impressions) and a short thumb with a capacity for abduction. 


\section{Animal Tracks}

Six animal tracks were discovered in the peripheral areas of the D3b-4 subunit. Their low level of conservation complicated their precise taxonomic attribution. Five of them are attributed to Carnivora (Felidae, Canidae and Mustelidae) and the last one to a Ruminantia (probably a Cervidae).

\section{Discussion}

Since 2012, the field missions yielded a large ichnological assemblage that makes Le Rozel a major track site. First of all, the 257 footprints represent to date the largest footprint sample attributed to a hominin taxon other than Homo sapiens. In particular, they form more than $95 \%$ of all the footprints attributed to Neandertals since only nine footprints had so far been attributed to this taxon (Fig. 11.1). Moreover, even for footprints attributed to Homo sapiens, such a large number is exceptional; the sites from the Willandra Lakes (e.g. Webb et al. 2006; Webb 2007) and the Hawaii Volcanoes National Park (Moniz Nakamura 2009) are among the few sites that yielded more footprints than Le Rozel. Also notable are the eight handprints recorded at Le Rozel that are to date the only Neandertal handprints available with the hand discovered at Maltravieso (Hoffmann et al. 2018). Besides the well-known positive and negative painted hands in rock art (e.g. Bahn 1998; Guthrie 2005), only a few handprints are known for Pleistocene hominins (Zhang and Li 2002; Mietto et al. 2003; Ledoux et al. 2017; Panarello et al. 2018). In addition, animal tracks provide information on fauna that lived near the site during the Palaeolithic occupations. For example, they attest to the presence of several carnivores of which no osteological remains had been found on the site (Cliquet et al. 2018a, b). Le Rozel tracks also represent an important discovery because of their association with archaeological material that attests to the occupations of the site by Neandertals. Such occupation contexts are rare among the other hominin footprint sites (Altamura et al. 2018); the majority of them only reflect passage areas (Masao et al. 2016; Roach et al. 2016; Bustos et al. 2018).

Except for the dimensions (Fig. 11.5b), it is difficult to morphologically compare the Le Rozel footprints with other footprints attributed to Neandertals because of their rarity as well as the differences in conservation and deposition conditions. Few anatomical details are reflected by these other footprints. Only a gap described as important between the hallux and the second toe has been reported for the most complete footprint discovered at Vârtop Cave (Onac et al. 2005). Such a space is not observed on the Le Rozel footprints, but this may be related to the nature of the substrate.

In that vein, some morphological features of the Le Rozel footprints, such as the lack of clear toe impressions on relatively complete footprints, raise a question: the possibility of shod feet. Such a feature could have a significant impact on our 
knowledge of Neandertal culture. No direct remains of shoes are known for Neandertals, and the earliest occurrences were discovered in Holocene sites (e.g. Kuttruff et al. 1998; Pinhasi et al. 2010). However, anatomical studies on the robustness of phalanges suggested a possible wearing of shoes as early as 30,000 years ago (Trinkaus and Shang 2008; see Trinkaus et al. Chap. 7). In addition, some footprints, such as one of those discovered at Theopetra Cave (Manolis et al. 2000; see Kyparissi-Apostolika and Manolis Chap. 10), have been described as prints of shod feet. Nevertheless, the associations between footprints and footwear are not certain, being generally based on qualitative criteria or on outliers in footprint dimensions (Bennett et al. 2010). Experimental studies on the same substrate conditions as at Le Rozel, and investigating morphometric differences between barefoot footprints and footwear (including shoes of varied rigidity), may provide significant information on this issue in the future.

Finally, we have shown that the 2012-2017 assemblage described here could provide direct information on the size and composition of the trackmaking groups; the assemblage from D3b-4 stratigraphic subunit represents a small group, most likely composed of 10-13 individuals, and $90 \%$ of the footprints correspond to children or adolescents (Duveau et al. 2019). This high proportion of children and adolescents raises questions about the distribution of activities (hunting, carcass transport, lithic industry, etc.) within the group. It is also currently impossible to know why so few adults were on the site at this time. Future analyses of the spatial distribution of footprints and their relationship to associated archaeological remains could provide valuable information on these important issues. Importantly, the two last field missions in 2018 and 2019 allowed the discovery of around 800 new potential footprints (most of them coming from the D3b-4 subunit). Ongoing studies of these new tracks will first have to validate or not their identification as hominin footprints. Then, morphometric analyses will aim to clarify our knowledge of the size and the composition of the groups who occupied Le Rozel 80,000 years ago.

To sum up, the tracks discovered at Le Rozel represent the most important ichnological assemblage attributed to Neandertals to date and more generally the most important for hominin taxa other than Homo sapiens. The analysis on the footprints provides not only essential data in order to understand the Palaeolithic occupations at Le Rozel 80,000 years ago but also could provide access to unique information on the composition of groups at a timescale unusual in prehistoric archaeology, that of a snapshot. In this perspective, the crossing of ichnological data with archaeological data (occupation structures, spatial distribution of activities, etc.) will bring closer to the life history of the Pleistocene human groups.

Acknowledgements Data concerning the site of Le Rozel was communicated by Dominique Cliquet in charge of the excavation and included in this contribution with his formal agreement; we thank him for this. Furthermore, we thank the owners of the Le Rozel site, Mrs. Lecomte, Mrs. Deregeaucourt, Mrs. Guillotte and Mrs. Maurouard. We wish to acknowledge all the volunteers who participated in the excavations, making the discovery and analysis of the archaeological and ichnological material possible. We are grateful to M. Friess and F. Detroit (Musée de l'Homme, Paris, France) for their help during the photogrammetric digitization. The field work is supported by the French Ministry of Culture and the French department of La Manche, and data acquisition has 
been funded by the CNRS-Institut Écologie et Environnement International Research Network IRN-GDRI0870. The first author was granted funding for a doctoral degree (Muséum national d'Histoire naturelle, Paris, France).

\section{References}

Aiello, L., \& Dean, C. (1990). An introduction to human evolutionary anatomy. New York: Academic Press.

Allen, J. R. (1997). Subfossil mammalian tracks (Flandrian) in the Severn Estuary, SW Britain: Mechanics of formation, preservation and distribution. Philosophical Transactions of the Royal Society of London B: Biological Sciences, 352(1352), 481-518.

Altamura, F., Bennett, M. R., D’Août, K., Gaudzinski-Windheuser, S., Melis, R. T., et al. (2018). Archaeology and ichnology at Gombore II-2, Melka Kunture, Ethiopia: Everyday life of a mixed-age hominin group 700,000 years ago. Scientific Reports, 8(1), 2815.

Ashton, N., Lewis, S. G., De Groote, I., Duffy, S. M., Bates, M., et al. (2014). Hominin footprints from early Pleistocene deposits at Happisburgh, UK. PLoS One, 9(2), e88329.

Bahain, J.-J., Falgueres, C., Laurent, M., Dolo, J.-M., Shao, Q., et al. (2015). ESR/U-series dating of faunal remains from the paleoanthropological site of Biache-Saint-Vaast (Pas-de-Calais, France). Quaternary Geochronology, 30, 541-546.

Bahn, P. G. (1998). The Cambridge illustrated history of prehistoric art. Cambridge: Cambridge University Press.

Bang, P., Dahlstrøm, P., \& Walters, M. (2001). Animal tracks and signs. Oxford: Oxford University Press.

Benazzi, S., Douka, K., Fornai, C., Bauer, C. C., Kullmer, O., et al. (2011). Early dispersal of modern humans in Europe and implications for Neandertal behaviour. Nature, 479(7374), 525.

Bennett, M. R., \& Morse, S. A. (2014). Human footprints: Fossilised locomotion? Heidelberg: Springer.

Bennett, M. R., Harris, J. W., Richmond, B. G., Braun, D. R., Mbua, E., et al. (2009). Early hominin foot morphology based on 1.5-million-year-old footprints from Ileret, Kenya. Science, 323(5918), 1197-1201.

Bennett, M. R., Gonzalez, S., Huddart, D., Kirby, J., \& Toole, E. (2010). Probable Neolithic footprints preserved in inter-tidal peat at Kenfig, South Wales (UK). Proceedings of the Geologists' Association, 121, 66-76.

Berillon, G. (2000). Le pied des hominoüdes miocènes et des hominidés fossiles: Architecture, locomotion et évolution. Paris: CNRS.

Bustos, D., Jakeway, J., Urban, T. M., Holliday, V. T., Fenerty, B., et al. (2018). Footprints preserve terminal Pleistocene hunt? Human-sloth interactions in North America. Science Advances, 4(4), eaar7621.

Citton, P., Romano, M., Salvador, I., \& Avanzini, M. (2017). Reviewing the upper Pleistocene human footprints from the 'Sala dei Misteri'in the Grotta della Bàsura (Toirano, Northern Italy) cave: An integrated morphometric and morpho-classificatory approach. Quaternary Science Reviews, 169, 50-64.

Cliquet, D., Auguste, P., Coutard, J.-P., Dupret, L., Duveau, J., et al. (2018a). Le site paléolithique moyen du « Pou » au Rozel (Manche) : des aires de travaux spécialisés et des habitats vieux d'environ 80000 ans. Un premier bilan. In J.-P. Olivier (Ed.), Journées archéologiques de Normandie, Rouen, 30 septembre-1er octobre 2016 (pp. 13-35). Mont Saint Agnan: Presses universitaires de Rouen et du Havre.

Cliquet, D., Coutard, J.-P., Van Vliet-Lanoë, B., Jamet, G., Auguste, P., et al. (2018b). Le Rozel (Manche), Le Pou, Section B $n^{\circ} 486$ et 572 (Rapport de fouille). Caen: SRA Normandie.

Crompton, R. H., \& Pataky, T. C. (2009). Stepping out. Science, 323, 1174-1175. 
Crompton, R. H., Pataky, T. C., Savage, R., D’Août, K., Bennett, M. R., et al. (2011). Human-like external function of the foot, and fully upright gait, confirmed in the 3.66 million year old Laetoli hominin footprints by topographic statistics, experimental footprint-formation and computer simulation. Journal of the Royal Society Interface, 9(69), 707-719.

de Lumley, H., \& Vicino, G. (1984). New data concerning the dating and interpretation of human footprints present in the "grotta della basura" at toirano (Savona, Northern Italy). Results of an international round table. Journal of Human Evolution, 13(6), 537-540.

Delson, E., \& Harvati, K. (2006). Palaeoanthropology: Return of the last Neandertal. Nature, 443(7113), 762.

Devièse, T., Karavanić, I., Comeskey, D., Kubiak, C., Korlević, P., et al. (2017). Direct dating of Neandertal remains from the site of Vindija cave and implications for the middle to upper Paleolithic transition. PNAS, 114(40), 10606-10611.

Dingwall, H. L., Hatala, K. G., Wunderlich, R. E., \& Richmond, B. G. (2013). Hominin stature, body mass, and walking speed estimates based on 1.5 million-year-old fossil footprints at Ileret, Kenya. Journal of Human Evolution, 64(6), 556-568.

Duveau, J., Berillon, G., Verna, C., Laisné, G., \& Cliquet, D. (2019). The composition of a Neandertal social group revealed by the hominin footprints at Le Rozel (Normandy, France). PNAS, 116(39), 19409-19414.

Falkingham, P. L. (2014). Interpreting ecology and behaviour from the vertebrate fossil track record. Journal of Zoology, 292, 222-228.

Farizy, C. (1994). Spatial patterning of middle Paleolithic sites. Journal of Anthropological Archaeology, 13(2), 153-160.

Finlayson, C., Pacheco, F. G., Rodríguez-Vidal, J., Fa, D. A., López, J. M. G., et al. (2006). Late survival of Neandertals at the southernmost extreme of Europe. Nature, 443(7113), 850.

Guipert, G., de Lumley, M. A., Tuffreau, A., \& Mafart, B. (2011). A late middle Pleistocene hominid: Biache-saint-Vaast 2, North France. Comptes Rendus Palevol, 10(1), 21-33.

Guthrie, R. D. (2005). The nature of Paleolithic art. Chicago: University of Chicago Press.

Harvati, K., \& Roksandic, M. (2016). The human fossil record from Romania: Early upper Paleolithic European mandibles and Neandertal admixture. In K. Harvati \& M. Roskandic (Eds.), Paleoanthropology of the Balkans and Anatolia (pp. 51-68). Dordrecht: Springer.

Hasiotis, S. T., Platt, B. F., Hembree, D. I., \& Everhart, M. J. (2007). The trace-fossil record of vertebrates. In S. T. Hasiostis et al. (Eds.), Trace fossils: Concepts, problems, prospects (pp. 196-218). Amsterdam: Elsevier.

Higham, T., Compton, T., Stringer, C., Jacobi, R., Shapiro, B., et al. (2011). The earliest evidence for anatomically modern humans in northwestern Europe. Nature, 479(7374), 521.

Hoffmann, D. L., Standish, C. D., García-Diez, M., Pettitt, P. B., Milton, J. A., et al. (2018). U-Th dating of carbonate crusts reveals Neandertal origin of Iberian cave art. Science, 359(6378), 912-915.

Hublin, J.-J. (2015). The modern human colonization of western Eurasia: When and where? Quaternary Science Reviews, 118, 194-210.

Jones, L. A., \& Lederman, S. J. (2006). Human hand function. Oxford: Oxford University Press.

Kim, J. Y., Kim, K. S., Lockley, M. G., \& Matthews, N. (2008). Hominid ichnotaxonomy: An exploration of a neglected discipline. Ichnos, 15(3-4), 126-139.

Klenerman, L., \& Wood, B. (2006). The human foot: A companion to clinical studies. Heidelberg: Springer.

Kuttruff, J. T., DeHart, S. G., \& O’Brien, M. J. (1998). 7500 years of prehistoric footwear from Arnold research cave, Missouri. Science, 281(5373), 72-75.

Leakey, M. D., \& Hay, R. L. (1979). Pliocene footprints in the Laetolil Beds at Laetoli, Northern Tanzania. Nature, 278(5702), 317-323.

Ledoux, L., Fourment, N., Maksud, F., Delluc, M., \& Costamagno, S. (2017). Traces of human and animal activity (TrAcs) in Cussac cave (Le Buisson-de-Cadouin, Dordogne, France): Preliminary results and perspectives. Quaternary International, 430, 141-154. 
Lockley, M., Roberts, G., \& Kim, J. Y. (2008). In the footprints of our ancestors: An overview of the hominid track record. Ichnos, 15(3-4), 106-125.

Lockley, M., Meldrum, J., \& Kim, J. Y. (2016). Major events in hominin evolution. In M. G. Mángano \& L. A. Buatois (Eds.), The trace-fossil record of major evolutionary events volume 2: Mesozoic and Cenozoic springer (pp. 411-448). Dordrecht: Springer.

Manolis, S., Aiello, L., Henessy, R., \& Kyparissi-Apostolika, N. (2000). Middle Palaeolithic footprints from Theopetra cave (Thessaly, Greece). In N. Kyparissi-Apostolika (Ed.), Theopetra cave. Twelve years of excavation and research 1987-1998 (pp. 87-93). Greek Ministry of Culture and Institute for Aegean Prehistory: Athens.

Masao, F. T., Ichumbaki, E. B., Cherin, M., Barili, A., Boschian, G., et al. (2016). New footprints from Laetoli (Tanzania) provide evidence for marked body size variation in early hominins. eLife, 5, e19568.

Mastrolorenzo, G., Petrone, P., Pappalardo, L., \& Sheridan, M. F. (2006). The Avellino 3780-yr-BP catastrophe as a worst-case scenario for a future eruption at Vesuvius. PNAS, 103(12), 4366-4370.

McLaren, D., Fedje, D., Dyck, A., Mackie, Q., Gauvreau, A., et al. (2018). Terminal Pleistocene epoch human footprints from the Pacific coast of Canada. PLoS One, 13(3), e0193522.

Mercier, N., Martin, L., Kreutzer, S., Moineau, V., \& Cliquet, D. (2019). Dating the palaeolithic footprints of 'Le Rozel'(Normandy, France). Quaternary Geochronology, 49, 271-277.

Mietto, P., Avanzini, M., \& Rolandi, G. (2003). Palaeontology: Human footprints in Pleistocene volcanic ash. Nature, 422(6928), 133.

Molleson, T. I., Oakley, K. P., \& Vogel, J. C. (1972). The antiquity of the human footprints of Tana della Basura. Journal of Human Evolution, 1(5), 467-471.

Moniz Nakamura, J. J. (2009). Hominid footprints in recent volcanic ash: New interpretations from Hawaii Volcanoes National Park. Ichnos, 16(1-2), 118-123.

Morse, S. A., Bennett, M. R., Gonzalez, S., \& Huddart, D. (2010). Techniques for verifying human footprints: Reappraisal of pre-Clovis footprints in Central Mexico. Quaternary Science Reviews, 29, 2571-2578.

Morse, S. A., Bennett, M. R., Liutkus-Pierce, C., Thackeray, F., McClymont, J., et al. (2013). Holocene footprints in Namibia: The influence of substrate on footprint variability. American Journal of Physical Anthropology, 151(2), 265-279.

Muñiz, F., Cáceres, L. M., Rodríguez-Vidal, J., de Carvalho, C. N., Belo, J., et al. (2019). Following the last Neandertals: Mammal tracks in Late Pleistocene coastal dunes of Gibraltar (S Iberian Peninsula). Quaternary Science Reviews, 217, 297-309.

Murie, O. J., \& Elbroch, M. (2005). A field guide to animal tracks. Singapore: Houghton Mifflin Harcourt.

Nigst, P. R., Haesaerts, P., Damblon, F., Frank-Fellner, C., Mallol, C., et al. (2014). Early modern human settlement of Europe north of the Alps occurred 43,500 years ago in a cold steppe-type environment. PNAS, 111(40), 14394-14399.

Onac, B. P., Viehmann, I., Lundberg, J., Lauritzen, S.-E., Stringer, C., et al. (2005). U-Th ages constraining the Neandertal footprint at Vârtop cave, Romania. Quaternary Science Reviews, 24(10-11), 1151-1157.

Pales, L. (1954). Les empreintes de pieds humains de la "Tana della Bàsura" (Toirano). Rivista di studi liguri, 20, 5-12.

Pales, L. (1960). Les empreintes de pieds humains de la "grotta della Basura". Rivista di studi liguri, 26, 25-90.

Panarello, A., Mazzardo, L., \& Mietto, P. (2018). The Devil's Touch: A first dataset from what could be the oldest handprint ever found (Central-Southern Italy). Alpine and Mediterranean Quaternary, 31(1), 37-47.

Pastoors, A., Lenssen-Erz, T., Ciqae, T., Kxunta, U., Thao, T., et al. (2015). Tracking in caves: Experience based reading of Pleistocene human footprints in French caves. Cambridge Archaeological Journal, 25(3), 551-564. 
Pastoors, A., Lenssen-Erz, T., Breuckmann, B., Ciqae, T., Kxunta, U., et al. (2017). Experience based reading of Pleistocene human footprints in Pech-Merle. Quaternary International, 430, $155-162$.

Pettitt, P. B. (1997). High resolution Neandertals? Interpreting middle palaeolithic intrasite spatial data. World Archaeology, 29(2), 208-224.

Pinhasi, R., Gasparian, B., Areshian, G., Zardaryan, D., Smith, A., et al. (2010). First direct evidence of chalcolithic footwear from the near eastern highlands. PLoS One, 5(6), e10984.

Pinhasi, R., Higham, T. F., Golovanova, L. V., \& Doronichev, V. B. (2011). Revised age of Late Neandertal occupation and the end of the middle Paleolithic in the northern Caucasus. PNAS, 108(21), 8611-8616.

Roach, N. T., Hatala, K. G., Ostrofsky, K. R., Villmoare, B., Reeves, J. S., et al. (2016). Pleistocene footprints show intensive use of lake margin habitats by Homo erectus groups. Scientific Reports, 6, 26374.

Rougier, H. (2003). Étude descriptive et comparative de Biache-Saint-Vaast 1 (Biache-Saint-Vaast, Pas-de-Calais, France). PhD thesis, Université de Bordeaux I.

Schmincke, H.-U., Rausch, J., Kutterolf, S., \& Freundt, A. (2010). Walking through volcanic mud: The 2,100 year-old Acahualinca footprints (Nicaragua) II: The Acahualinca people, environmental conditions and motivation. International Journal of Earth Sciences, 99(1), 279-292.

Scuvée, F., \& Verague, J. (1984). Paléolithique supérieur en Normandie occidentale: l'Abri-sousRoche de la Pointe du Rozel (Manche). Cherbourg: LITTUS CEHP.

Sévêque, N. (2017). Variabilité des comportements alimentaires au Paléolithique moyen en France septentrionale: apports des études archéozoologiques. $\mathrm{PhD}$ thesis, Unviersité de Lille 3.

Soficaru, A., Petrea, C., Doboş, A., \& Trinkaus, E. (2007). The human cranium from the Peştera Cioclovina Uscată, Romania: Context, age, taphonomy, morphology, and paleopathology. Current Anthropology, 48(4), 611-619.

Stoetzel, E., Koehler, H., Cliquet, D., Sévêque, N., \& Auguste, P. (2016). New data on Late Pleistocene small vertebrates from northern France. Comptes Rendus Palevol, 15(6), 681-695.

Trinkaus, E., \& Shang, H. (2008). Anatomical evidence for the antiquity of human footwear: Tianyuan and Sunghir. Journal of Archaeological Science, 35(7), 1928-1933.

Trinkaus, E., Churchill, S. E., Villemeur, I., Riley, K. G., Heller, J. A., et al. (1991). Robusticity versus shape: The functional interpretation of Neandertal appendicular morphology. Journal of the Anthropological Society of Nippon, 99(3), 257-278.

Trinkaus, E., Moldovan, O., Bîlgăr, A., Sarcina, L., Athreya, S., et al. (2003). An early modern human from the Peştera cu Oase, Romania. PNAS, 100(20), 11231-11236.

Tuffreau, A. (1978). Les fouilles du gisement paléolithique de Biache-Saint-Vaast (Pas-de-Calais): années 1976 et 1977-premiers résultats. Quaternaire, 15(1), 46-55.

Tuffreau, A. (1988). Les habitats du Paléolithique inférieur et moyen dans le Nord de la France (Nord, Pas-de-Calais, Somme). Revue archéologique de Picardie, 1(1), 91-104.

Valladas, H., Mercier, N., Froget, L., Joron, J.-L., Reyss, J.-L., et al. (2007). TL age-estimates for the middle Palaeolithic layers at Theopetra cave (Greece). Quaternary Geochronology, 2(1-4), 303-308.

van Vliet-Lanoë, B., Cliquet, D., Auguste, P., Folz, E., Keen, D., et al. (2006). L'abri sous-roche du Rozel (France, Manche): un habitat de la phase récente du Paléolithique moyen dans son contexte géomorphologique. Quaternaire, 17(3), 207-258.

Viehmann, I. (1987). Prehistoric human footprints in Romania's caves. Theoretical and Applied Karstology, 3, 229-234.

Webb, S. (2007). Further research of the Willandra Lakes fossil footprint site, southeastern Australia. Journal of Human Evolution, 52(6), 711.

Webb, S., Cupper, M. L., \& Robins, R. (2006). Pleistocene human footprints from the Willandra Lakes, southeastern Australia. Journal of Human Evolution, 50(4), 405-413.

Webb, D., Robu, M., Moldovan, O., Constantin, S., Tomus, B., et al. (2014). Ancient human footprints in Ciur-Izbuc cave, Romania. American Journal of Physical Anthropology, 155(1), 128-135. 
Wood, R. E., Barroso-Ruíz, C., Caparrós, M., Pardo, J. F. J., Santos, B. G., et al. (2013). Radiocarbon dating casts doubt on the late chronology of the middle to upper Palaeolithic transition in southern Iberia. PNAS, 110(8), 2781-2786.

Zhang, D. D., \& Li, S. H. (2002). Optical dating of Tibetan human hand-and footprints: An implication for the palaeoenvironment of the last glaciation of the Tibetan Plateau. Geophysical Research Letters, 29(5), 16-11.

Open Access This chapter is licensed under the terms of the Creative Commons Attribution 4.0 International License (http://creativecommons.org/licenses/by/4.0/), which permits use, sharing, adaptation, distribution and reproduction in any medium or format, as long as you give appropriate credit to the original author(s) and the source, provide a link to the Creative Commons license and indicate if changes were made.

The images or other third party material in this chapter are included in the chapter's Creative Commons license, unless indicated otherwise in a credit line to the material. If material is not included in the chapter's Creative Commons license and your intended use is not permitted by statutory regulation or exceeds the permitted use, you will need to obtain permission directly from the copyright holder.

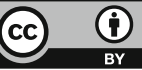

